\title{
OFDI Entry Modes and Firms' Innovation: Evidence from Chinese A-Share Listed Firms
}

\author{
Chunhuan Xiao, Ziyin Zhuang * and Amei Feng
}

check for updates

Citation: Xiao, C.; Zhuang, Z.; Feng, A. OFDI Entry Modes and Firms' Innovation: Evidence from Chinese A-Share Listed Firms. Sustainability 2021, 13, 7922. https: / / doi.org/10.3390/ su13147922

Academic Editor: Matteo Rossi

Received: 13 June 2021

Accepted: 12 July 2021

Published: 15 July 2021

Publisher's Note: MDPI stays neutral with regard to jurisdictional claims in published maps and institutional affiliations.

Copyright: (c) 2021 by the authors. Licensee MDPI, Basel, Switzerland. This article is an open access article distributed under the terms and conditions of the Creative Commons Attribution (CC BY) license (https:// creativecommons.org/licenses/by/ $4.0 /)$.
School of Economics and Management, Wuhan University, Wuhan 430072, China; xiaochunhuan@whu.edu.cn (C.X.); ameifeng001@163.com (A.F.)

* Correspondence: zyzhuang@whu.edu.cn

\begin{abstract}
Innovation is crucial for firms' sustainable development. However, the original motivation of innovation in China is insufficient and the key technology is controlled by other countries. Outward foreign direct investment (OFDI) is an important strategic choice in emerging economies to seek overseas advantageous technical knowledge and to participate in global competition. With the further development of China's "go global" strategy, OFDI flows have risen considerably. Whether OFDI can promote firms' innovation levels and whether OFDI entry modes (greenfield investment and cross-border M\&A) have the same impact are still major issues to be solved. Therefore, we constructed a mathematical model and adopted the propensity score matching double difference method to analyze the impact and mechanism of OFDI on firms' innovation. The results show that OFDI has a significant effect on innovation quantity, quality, and efficiency, and it has not led to innovative strategic behavior. Further research shows that cross-border M\&A has a stronger effect on innovation quality than greenfield investment, and both have a sustainable innovation effect. Over time, the gap between the impact of greenfield investment and cross-border M\&A on innovation quality has gradually narrowed. From the perspective of mechanism, the two entry modes of OFDI are beneficial to firms' access to government resources and to promote innovation quality, while government resources have a stronger mediating effect on cross-border M\&A firms. This paper deepens the research on the influence mechanism of OFDI entry modes on firms' innovation levels, while also providing theoretical and practical support for the selection of OFDI modes and innovation strategies for firms.
\end{abstract}

Keywords: innovation quality; innovation efficiency; outward foreign direct investment (OFDI); greenfield investment; cross-border M\&A; government resources

\section{Introduction}

Innovation is vital to the survival and sustainable development of firms and it is the "engine" of economic growth. Since 1985, China's patent applications have shown an explosive growth, ranking 14th in the 2020 Global Innovation Index report. China has achieved tremendous development in science and technology and significantly improved its capacity for independent innovation over recent decades. However, original innovation ability in science and technology is seriously insufficient, and the core technology is highly dependent on foreign countries in China, such as the lack of significant original achievement and underlying basic technology. The situation that key technologies are controlled by other countries has not been fundamentally changed [1]. In addition, not only micro-level strategic innovation behavior problems are prominent, but innovation efficiency also has a large gap when compared with developed economies (i.e., the United States and Japan), which all restrict China's economic transformation, upgrading and high-quality development [2,3]. In consequence, some studies suggest that OFDI is used by emerging economy firms to achieve "overtaking at the corner" in technology, resulting from obtaining cutting-edge technologies [4]. OFDI is not just the most efficient response 
for firms to cope with fierce industry competition and to supplement the lack of internal knowledge resources to quickly acquire innovation resources, but also the most rapid and effective growth strategy [5-9]. The national strategy attaches great importance to improving the level of firm innovation through OFDI.

In 2000, the fifth plenary session of the 15th CPC Central Committee put forward the strategy of "go global" for the first time, which is also known as the international business strategy. It refers to Chinese firms making full use of "two markets and two resources home and abroad" and to actively participate in international competition and cooperation through foreign direct investment, foreign labor service cooperation, and other forms. The government encourages and supports qualified firms to conduct overseas mergers and acquisitions, deepening mutually beneficial cooperation in overseas resources and realizing the strategy of making China a great modern country with sustainable economic development. With the deepening of the "go global" strategy, OFDI has made significant breakthroughs in both the scale and the field of investment. By the end of 2019, the stock of OFDI by Chinese firms had reached USD 2.2 trillion, covering more than $80 \%$ of the world's countries and regions, and over 27,500 domestic investors had set up 44,000 firms overseas. The scale and fields of OFDI have made significant breakthroughs. Some countries and regions in Europe and the United States are even concerned about the enhancement of the innovation ability of Chinese firms; thus, they have implemented stricter security reviews of the OFDI of Chinese firms. Meanwhile, the COVID-19 pandemic has worsened the political and economic tensions between China and the United States to a certain extent, which has a superimposed impact on the overseas investment of Chinese firms. Therefore, in the current situation that "innovation is the first driving force to guide development", can fast-growing OFDI promote the innovation of domestic firms? Whether it is for firms or the economic development of a country is an important topic.

Does OFDI promote domestic firms' innovation? This question has drawn much attention, but the research conclusions are inconsistent. There is extensive literature suggesting that OFDI plays a multichannel role in promoting firms' innovation. For example, Stiebale argues that direct learning and obtaining complementary R\&D resources from overseas target firms through OFDI is beneficial to breaking the path dependence of technological innovation, changing the original firms' innovative thinking, and promoting firms' innovation [10]. Yan et al. argue that firms transfer R\&D technologies to foreign countries through OFDI to improve the efficiency of the allocation of innovation resources, which enables enterprises in their home countries to use core resources for domestic innovation [11]. Jia et al. suggest that OFDI can bring about the economies of scale effect, which can reduce production costs. Subsequently, it promotes domestic firms to increase human capital and R\&D investment through the profit feedback effect, so as to improve productivity and realize independent innovation [12]. However, other studies show that OFDI has a negative effect on firms' innovation. The resource integration and adjustment costs brought by the disadvantage of outsiders and new entrants, cultural systems, and other differences when firms undertake OFDI lead to technology spillover and unsatisfactory performance [13-15]. At the same time, large-scale OFDI tends to crowd out domestic investment, which is not conducive to the independent innovation of the home economies [16]. Another perspective is that OFDI's impact on firms' domestic innovation is uncertain $[17,18]$. Therefore, conclusions on the impact of OFDI on firms' innovation are inconsistent. Most studies argue that this is restricted by factors such as OFDI motivation, industrial heterogeneity of firms, regional differences, characteristics of host countries, and the coexistence of "positive gradients" and "negative gradients", which leads to greater differences between different OFDI entry modes [19-21]. Resource-based theory holds that the unique resources available to the firm determine their competitive advantage [22]. Different entry modes of OFDI mean different resource acquisition channels, internal and external costs, and risk exposure of multinational firms, which directly affect the innovation of multinational firms. 
Therefore, some authors emphasize that the meaning of greenfield investment and cross-border M\&A should be distinguished when studying the entry modes of OFDI. Cross-border M\&A refers to the merger and acquisition activities of the home firms in order to obtain the controlling right of the host country firms. Greenfield investment refers to the activities in which investors set up local firms in accordance with the laws of the host country in order to acquire the ownership of part or all of the assets. Current literature mainly studies OFDI entry modes from three aspects. Firstly, schools of thought may be classified into economic and business studies, such as industrial organization, financial economics, strategic management, and organizational behavior $[21,23,24]$. Secondly, some literature studies OFDI entry modes from the perspective of industry and national factors, such as the industry's technology and R\&D density, the country's market growth potential, culture, and institutions etc. [23]. Thirdly, other literature is based on the perspective of heterogeneous enterprises. Instead of the single heterogeneity of productivity, they gradually expand to the scale of enterprises, capital structure, financing constraints on R\&D investment, and the level of economic development, geographical distance, tax level, institutional environment, and other factors [25-31]. The entry modes of OFDI have always been the focus of academic research, but it is generally limited to the analysis of the selection mechanism and influencing factors. Very few studies have considered the internal relationship between OFDI entry modes and firms' innovation.

In recent years, the development trend of M\&A and greenfield investment of Chinese multinational firms has begun to diverge. Under the background of a sharp decline in the total amount of global and Chinese OFDI, greenfield investment flows by Chinese firms, which are mainly characterized by the transfer of production capacity, have shown a trend of steady appreciation. In 2017, it rose to USD 31.6 billion, an increase of $53.7 \%$ over the previous year. In 2018, it fell slightly to USD 29.7 billion, a decrease of $6.0 \%$, and then hit a record high in 2019, reaching USD 37.2 billion, an increase of $25.3 \%$. By contrast, M\&A transaction flows by firms with the main motivation of seeking technology and strategic resources fluctuated significantly, from USD 9.46 billion in 2017 to USD 12.02 billion, an increase of $27.1 \%$. However, in 2019, it dropped sharply to USD 1.4 billion, a decrease of $88.4 \%$, showing a cliff-like decline. The market will have a strong wait-and-see mood due to the COVID-19 pandemic, the sharp global economic recession, and the intensifying geopolitical competition among major countries. Therefore, rational evaluation of greenfield investment and cross-border M\&A of firms can provide theoretical and empirical support for national policy stability and firms' OFDI mode selection. It is urgent to conduct a comparative analysis of the impact of greenfield investment and cross-border M\&A from the perspective of innovation.

Concurrently, we cannot ignore the role of the government in the ecosystem of open innovation [32]. Against the background of an imperfect institutional environment, the government is still the major participant in Chinese economic activities. The government has an important influence on the innovation behavior of firms, which often improves the firms' bargaining power and enhances the competitive platform through the direct allocation of resources in practice, so as to promote the innovation of firms $[33,34]$. Therefore, it is of great significance to study the influence of government resources on the innovation level of OFDI firms.

In recent years, papers on OFDI by emerging economies have grown rapidly; however, there are still the following shortcomings. Firstly, the existing research generally analyzes the impact of OFDI on firms' innovation, but the research on different entry modes of Chinese multinational firms lacks a systematic and complete explanation and a unified analytical framework or platform to discuss different results. Secondly, previous studies are generally limited to the selection mechanism of OFDI entry modes and the analysis of influencing factors. Little literature focuses on the impact of OFDI entry modes on firms' innovation performance, which ignores the impact on innovation quality and efficiency. Finally, in a period of economic transformation in China, the government is still the main participant in economic activities. Most of the literature studies the role of the 
government based on institutional theory, while neglecting the heterogeneous influence of the government on different OFDI entry modes. Based on the above analysis, we select China as the research object, which represents an emerging economy, to study whether OFDI can promote the innovation of domestic enterprises, and to further compare and analyze whether different entry modes of OFDI have the same impact on firms' innovation. At the same time, we investigate the mediating role of government resources on the innovation effect of OFDI entry modes based on the signal theory.

Possible marginal contributions of this paper are as follows. 1. We constructed a mathematical model to study the impact of OFDI on firms' innovation, which enriches the cross-study of OFDI and firms' innovation. 2. Previous comparative studies on the impact of greenfield investment and cross-border M\&A on firms' innovation lack systematic and complete explanations. Moreover, these studies mainly use the data of European and American countries and regions, but rarely used the data of Chinese firms. We provide empirical data from developing countries in this field. 3. Different from previous studies, based on the signal theory, we have confirmed the signal mechanism of greenfield investment and cross-border M\&A, and provided empirical basis and theoretical support for the signal function of greenfield investment and cross-border M\&A to obtain government resources. The influencing mechanism of OFDI entry modes on innovation effect is extended. 4. Different from most literature focusing on the relationship between OFDI entry modes and firms' performance, we emphasize the influence on firms' innovation quantity, quality, and efficiency. We measure the innovation level of firms more comprehensively from multiple perspectives. Against the background of the rapid development of China's OFDI, but with several doubts, the study of OFDI entry modes from the perspective of innovation can not only provide theoretical and practical support for innovation strategy and OFDI policy at the national level, but also provide a beneficial reference for firms' innovation and OFDI decision making.

\section{Theoretical Background and Hypotheses}

This study builds a model to analyze the innovation effect of firms' OFDI, and compares the impact of different OFDI entry modes on firms' innovation on this basis.

\subsection{OFDI and Firms' Innovation}

There are great differences between China's OFDI and developed countries' OFDI in OFDI motivation and flow direction. Developed countries are usually strong in economy and leading in technology. Their OFDI has monopoly advantages in capital, technology, and scale, and their investment goal is often to obtain high profits. They tend to target the relatively backward industries. They can exploit the market to achieve the economies of scale by virtue of their own advantages in technology and management experience, rich local natural resources, and cheap labor. However, as a representative of emerging economies, China's current level of economic development and innovation capacity within the global range is approximately in the middle, whose advantages of scale economy and internalization of Chinese enterprises are not obvious. In addition, Chinese multinational firms are investing abroad in search of technology or markets, not labor resources. They acquire strategic resources and learn advanced knowledge to cultivate a higher level of competitive advantage through OFDI in developed countries, so as to make up for their competitive disadvantage and to improve their independent innovation ability. They exploit new markets and optimize resource allocation by taking advantage of their existing advantages through foreign direct investment in countries with more backward economic development, maximizing the use of their proprietary knowledge and realizing independent innovation.

Based on the mathematical model of $\mathrm{d}^{\prime}$ Apremont and Jacquemin and the research of Chen and Zhang [35,36], this paper discusses and analyzes the relationship between OFDI and firms' innovation. We established a local equilibrium model of two countries and two firms, which was based on the Cournot model of oligarchic markets. Suppose 
$\mathrm{i}=\{1,2\}$ and $\mathrm{j}=\{1,2\}, \mathrm{F}_{\mathrm{ij}}$ stands for $\mathrm{i}$ firms in country $\mathrm{j}$, the inverse demand function of two competing firms producing homogeneous products is:

$$
P_{j}=p\left(Q_{j}\right)=\left(a-q_{i j}-q_{k j}\right)(i \neq k)
$$

where $q_{i j}$ and $q_{k j}$, respectively, represent the output of firms i and firms $k$ in country $j, Q_{j}$ is the total output of country $\mathrm{j}, \mathrm{P}$ is the price. To simplify the calculation, it is supposed that there is no fixed cost in the production process. $C$ represents the marginal cost and also the cost or technology gap between China and firms in other countries. In order to improve efficiency and reduce marginal cost, firms will invest in innovation to obtain greater benefits. Innovation investment follows the law of diminishing marginal returns and the R\&D cost of the firms is set as: $\Gamma\left(x_{i j}\right)=\frac{1}{2} \alpha_{j} x_{i j}{ }^{2}, \alpha_{j}>0, \alpha_{j}$ is the cost parameter of firms' innovation, which decreases with the increase of innovation level. Whether a firm has OFDI behavior can be divided into the following two situations.

\subsubsection{No OFDI Occurs}

When the firms do not engage in OFDI activities, the cost and profit of firms $F_{i j}$ are as follows:

$$
\begin{gathered}
C_{i j}=\left(C-x_{i j}\right) q_{i j}+\frac{1}{2} \alpha_{j} x_{i j}^{2} \\
\pi_{i j}=\left(a-Q_{j}\right) q_{i j}-\left(C-x_{i j}\right) q_{i j}-\frac{1}{2} \alpha_{j} x_{i j}^{2}
\end{gathered}
$$

In Equation (3), the equilibrium value of innovation input can be obtained by taking the derivative of the first order of $\mathrm{q}_{\mathrm{ij}}$ and $\mathrm{x}_{\mathrm{ij}}$ :

$$
\mathrm{x}_{\mathrm{ij}}^{*}=\frac{4(\mathrm{a}-\mathrm{C})}{9 \alpha_{\mathrm{j}}-4}
$$

According to Equation (3), when firms' innovation input is zero, the conditions for firms' sustainable survival is a $-C>0$. According to Equation (4), when $\alpha_{j}>4 / 9, \alpha_{j}$ changes in inverse proportion to $x_{\mathrm{ij}}^{*}$. That is, when a country's innovation level is low, the firms will invest more in innovation. Due to the law of diminishing innovation marginal effect, when a country's innovation level reaches a certain level, i.e., $0<\alpha_{j}<4 / 9$, firms will no longer invest in innovation.

\subsubsection{OFDI Occurs}

When the firms engage in OFDI activities, the firms' cost and profit $\mathrm{F}_{\mathrm{ij}}$ are as follows:

$$
\begin{gathered}
C_{i j}=\left(C-x_{i j}-\delta_{i l} x_{i l}\right) q_{i j}+\frac{1}{2} \alpha_{j} x_{i j}^{2}(j \neq 1) \\
\pi_{i j}=\left(a-Q_{j}\right) q_{i j}-\left(C-x_{i j}-\delta_{i l} x_{i l}\right) q_{i j}-\frac{1}{2} \alpha_{j} x_{i j}{ }^{2}(j \neq 1)
\end{gathered}
$$

where $\delta_{\mathrm{il}}$ represents the transformation and utilization level of innovation resources when firms undertake OFDI, which meets $\delta_{\mathrm{il}}>0$. In Equation (6), the equilibrium value of innovation input can be obtained by taking the derivative of the first order of $\mathrm{q}_{\mathrm{ij}}$ and $\mathrm{x}_{\mathrm{ij}}$ :

$$
x_{i j}^{*}=\frac{4(a-C)\left(3 \alpha_{j}-4\right)+8 \delta_{i l} x_{i l}\left(3 \alpha_{j}-2\right)}{\left(3 \alpha_{j}-4\right)\left(9 \alpha_{j}-4\right)}
$$

According to Equation (7), when $4 / 9<\alpha_{\mathrm{j}}<2 / 3$ or $\alpha_{\mathrm{j}}>4 / 3, \mathrm{x}_{\mathrm{ij}}^{*}>0$, it means that the firms will continue to invest in innovation after OFDI; when $2 / 3<\alpha_{j}<4 / 3$, the innovation effect of firms is determined by the relative size of $\delta_{\mathrm{il}} \mathrm{x}_{\mathrm{il}}$ and $(\mathrm{a}-\mathrm{C})$. 
By comparing the change of innovation input before and after OFDI, the following formula can be obtained:

$$
\Delta \mathrm{x}_{\mathrm{ij}}^{*}=\frac{\delta_{\mathrm{il}} \mathrm{x}_{\mathrm{il}}\left(3 \alpha_{\mathrm{j}}-2\right)}{\left(3 \alpha_{\mathrm{j}}-4\right)\left(9 \alpha_{\mathrm{j}}-4\right)}
$$

When the firms' innovation level meets $4 / 9<\alpha_{j}<2 / 3$ or $\alpha_{j}>4 / 3$, OFDI will promote firms' innovation; when $2 / 3<\alpha_{j}<4 / 3$, OFDI will inhibit firms' innovation. Clearly, when a country has a low level of firms' innovation and OFDI is an engine for firms with a high level of innovation, firms must continue to invest in innovation, and to digest and absorb these new technologies, so as to promote enterprise innovation. When a country's firms have a low level of innovation, foreign direct investment to firms with higher level of innovation will lead to intensified competition. In order to obtain opportunities for foreign direct investment, firms often have greater motivation to carry out independent innovation. When firms' innovation levels are in the middle, the motivation to improve digestion and absorption capacity and for independent innovation are relatively low; thus, the technical knowledge brought by OFDI will often inhibit the motivation of continuous firm innovation. This study accordingly proposes the following hypotheses:

Hypothesis 1. Based on the fact that the original innovation ability of Chinese firms is not high, OFDI has a significant positive relationship with innovation quantity, innovation quality, and innovation efficiency.

\subsection{The Relationship between OFDI's Different Entry Modes and Firms' Innovation}

According to Equation (8), when firms undertake OFDI, their innovation effect depends on the transformation ability of their innovation resources. Hence, what are the differences in the impact of different entry modes of OFDI on firms' innovation effects? How do they change over time?

Firstly, the transformation abilities of firms' resources are affected by the differences in market norms and systems. If these differences are great, it is easy to hinder technology transfer and affect the absorption and utilization of new knowledge. Greenfield investment brings additional production capacity, which is more likely to cause uncertainty risks, such as exclusion and retaliation of incumbent firms. Moreover, it is relatively unfamiliar to the host country's government, consumers, culture, and system, and has certain disadvantages compared with local incumbent firms. This entry mode needs a relatively long time to operate because it is difficult to embed and to acquire the local resources of the host country [37]. In order to adapt to the external environment, new firms need to be familiar with local laws and policies, understand local habits and preferences, and develop cooperative relationships with local governments, suppliers, and distributors, which incur a series of external costs. These costs will be more prominent in the first few years of greenfield investment, but as time goes by, the firm will gradually overcome the adverse effects of initial foreign firms through accumulation of experience. In contrast, there will not be many external costs when firms choose M\&A because most of the acquired firms will have been operating for many years and will have relatively stable cooperative relations with other organizations. They are already familiar with the local market environment and understand the preferences of local consumers, and have formed their own brand and reputation in the local area.

Secondly, the transformation ability of firms' resources is affected by the cost of internal resources integration. At the beginning, M\&A firms adopt localization strategy, which will not exert too much pressure on the integration of internal resources, but as time goes by, they will gradually strengthen the coordination and connection between the parent company and its subsidiaries and increase the integration of its subsidiaries due to the consideration of globalization strategy. At this time, the cost of resource integration generated by M\&A is relatively large. Specifically, the post-merger firms will adjust, reorganize, or integrate according to the parent company's culture, production, brand, personnel, etc., in order to integrate the merged firms into the operation and management mode of the parent 
company. The cost of integration and coordination caused by misunderstanding and conflict in the process of integration will have a negative impact on the firms' innovation effect. However, greenfield investment firms have maintained close contact with the parent company in the early stage, so there are resources integration costs at the beginning $[38,39]$. Therefore, the cost of internal resource integration for greenfield investment is greater than that of M\&A. In conclusion, the innovation effect of firms' resource conversion ability is different due to the difference in external and internal costs of resource integration. We consequently propose the following Hypotheses 2 and 3 :

Hypothesis 2. Cross-border MEA has a stronger promotion effect on innovation quality than greenfield.

Hypothesis 3. The difference in innovation effects between cross-border MEA and greenfield investment becomes smaller as time goes by.

\subsection{The Mediating Role of Government Resources}

Based on the signal theory, this study discusses the influence of different OFDI entry modes on firms' innovation. Firms' innovation activities need to consume a large amount of resources, and whether they can obtain the support and cooperation of stakeholders in these resources is the key to the success of their innovation activities [40-42]. Due to the information asymmetry in firms' innovation activities, stakeholders perceive stronger risks and reduce support for innovation resources [43,44]. The cause of information asymmetry is as follows. 1. Firms have their own product advantages, market prospects, expected risks, and other information. For undisclosed reasons, they don't want to fully open the intended market, or it is difficult for the public to understand the technical knowledge even if it is open, which leads to information asymmetry. 2. We usually need to pay high screening costs to select excellent firms. Specifically, we need corresponding human and material resources to collect and study the information disclosed by firms, which will lead to adverse selection and moral hazard.

Greenfield investment or cross-border M\&A by firms can be regarded as a positive response to policy orientation. It reflects a good relationship between firms and policies, which can enhance the trust of the government in these firms. Such relationships can endow firms with stronger legitimacy [45] and, to a certain extent, reduce external investors' concerns about their credit, which is conducive to promoting government support for firms' innovation activities and making it easier for firms to access government resources. Therefore, based on their trust in firms, the government believes that such firms have innovative capabilities to reduce the risk of policy failure. The above indicates that firms engaged in greenfield investment and cross-border M\&A can convey a positive signal to stakeholders that they are "capable" and "trustworthy", thus effectively reducing the degree of information asymmetry and enabling firms to obtain positive evaluation and innovation resource support from stakeholders. Compared with greenfield investment, cross-border M\&A targets are usually mature and well-developed firms in European and American developed countries, whose asset value and capital scale are larger [46]. Therefore, grafting government resources is more important for the innovation and development of transnational firms. Accordingly, we propose the following Hypotheses 4:

Hypothesis 4. Government resources mediate the relationship between the two OFDI entry modes and innovation, while having a stronger intermediary effect on cross-border $M \mathcal{E} A$.

\section{Methods}

\subsection{Samples and Data}

Considering integrity and availability of data, we selected Chinese A-share listed firms from 2010 to 2018 as the samples. Data of OFDI, greenfield investment, and cross-border M\&A are from the CSMAR and BVD-Zephyr databases, respectively. The principles of data cleansing were as follows. 1 . We excluded listed firms with significant data gaps and 
deleted samples of companies in sectors such as ST and finance and insurance. 2. We only considered deals which were considered completed or completed assumed. 3 . In order to exclude the mixed impact in the sample period, we only retained the samples of the first greenfield investment and cross-border M\&A events. 4. We discarded the sample data of firms that conduct both, to avoid the cross-influence of greenfield investment and cross-border M\&A. 5. We reserved the year before the OFDI event as the initial period to conduct preference score matching year by year. More specifically, we matched the financial information for all firms listed at China's major stock exchange markets at Shanghai and Shenzhen in the Wind Database and iFinD Database with these cross-border M\&A deals to obtain a sample of cross-border M\&A. We matched the financial information with the greenfield deals from the CSMAR database via the firms' codes in order to obtain a sample of greenfield investment. We finally obtained 681 foreign direct investment events from 2010 to 2018, of which 257 were cross-border M\&A and 424 were greenfield investments. 6. Finally, we performed a $1 \%$ tailing process on the data to eliminate extreme effects. Other relevant data used were from the iFinD Database, Wind Info, and the China National Intellectual Property Patent Search Database.

\subsection{Key Variables}

\subsubsection{Dependent Variables}

Current research on the measurement of innovation has a variety of methods, such as focusing on the perspective of innovation input. Several studies use R\&D spending as the measurement of innovation [12], which is only one part of the innovation input and cannot reflect all innovation activities, such as the establishment of human resources and innovation networks, and the introduction and absorption of new knowledge [47]. In addition, the reduction in $R \& D$ expenditure may be due to the increase in $R \& D$ efficiency brought about by the company's scale effect excluding repetitive R\&D investment [48], but does not necessarily mean the reduction of corporate R\&D activities. Input cannot ultimately reflect the quality of innovation output. Therefore, this paper measures the change of firms' innovation levels from the perspective of innovation output, using the index of patent application numbers. According to the research of Ahuja and Katila, patents reflect the technological innovation of enterprises and are closely related to the innovation output. They are economic assets with real value. We hoped to measure more comprehensively the level of innovation of firms from multiple perspectives. Therefore, following the method of several papers [49-51], we used the number of patent applications as the measurement index of the firms' innovation quantity, the application of invention patent as the measurement index of the firms' innovation quality, and the number of patent applications against total R\&D expenditure of the current year and the previous two years divided by the total assets of the firms as the measurement index of innovation efficiency. We also used the ratio of the number of non-invention patent applications to the total number of patent applications granted to construct variables reflecting strategic innovation propensity.

\subsubsection{Independent Variables}

We focused on analyzing the impact of OFDI and different OFDI entry modes on firms' innovation. Therefore, the samples were divided into four groups: enterprises with OFDI, enterprises only engaging in greenfield investment, enterprises only participating in crossborder M\&A as the experimental group, and enterprises with neither greenfield investment nor cross-border M\&A as the control group. The main independent variables of interest are OFDI and Model_ $\tau(\tau=1,2)$. OFDI represents whether or not a firm engages in OFDI, Model_ $\tau(\tau=1,2)$ represents whether greenfield $(\tau=1)$ or M\&A $(\tau=2)$ is performed. When the value is 1 , it is yes, and 0 otherwise. 


\subsubsection{Control Variables}

According to relevant research $[35,40,52]$, this paper controlled the variables related to firms' innovation. These variables include investment in technological innovation, number of employees, ownership, return on assets, and the setting of specific variables of labor productivity. The key variables are shown in Table 1.

Table 1. Variables and measurements.

\begin{tabular}{|c|c|c|}
\hline Variable & Variable Name & Variable Measurement \\
\hline \multirow[t]{5}{*}{ Dependent variable } & LnIQ & $\begin{array}{l}\text { Innovation quantity, natural log of the number of } \\
\text { patent applications plus } 1\end{array}$ \\
\hline & LnIQ1 & $\begin{array}{c}\text { Innovation quality, natural } \log \text { of the number of } \\
\text { patent for invention applications plus } 1\end{array}$ \\
\hline & & Innovation efficiency, the number of patent \\
\hline & LnIE & $\begin{array}{l}\text { applications / (total R\&D expenditure for the current } \\
\text { year and the previous two years/current total assets) }\end{array}$ \\
\hline & LnSI & $\begin{array}{l}\text { Strategic innovation, number of non-invention } \\
\text { patents / total number of patent applications }\end{array}$ \\
\hline \multirow[t]{2}{*}{ Dependent variable } & OFDI & $\begin{array}{c}\text { Dummy variable coded as } 1 \text { if OFDI occurs in } \\
\text { current year and } 0 \text { otherwise }\end{array}$ \\
\hline & Model_ $\tau$ & $\begin{array}{l}\text { Model_1 is the cross-border M\&A companies and } \\
\text { Model_2 is the greenfield firms }(\tau=1,2)\end{array}$ \\
\hline \multirow[t]{5}{*}{ Control variables } & Rdrate & $\begin{array}{l}\text { Commercial credit, R\&D spending/ } \\
\text { operating income }\end{array}$ \\
\hline & Ownship & $\begin{array}{l}\text { Dummy variable coded as } 1 \text { if the company is a } \\
\text { state-owned firm and } 0 \text { otherwise }\end{array}$ \\
\hline & ROA & Return on assets \\
\hline & Lnw & Natural log of the number of workers \\
\hline & Lntfp & Natural log of total factor productivity (LP method) \\
\hline
\end{tabular}

\subsection{Model}

The current research shows that whether the engine in OFDI and entry modes of OFDI are non-random depends on the internal factors of firms. For example, the firms themselves have invested more R\&D funds and manpower, have higher innovation ability, and are more inclined to carry out OFDI, which is the self-selection effect of OFDI. In addition, firms can improve their innovation level to a certain extent by learning foreign advanced technology and management experience when conducting OFDI activities; that is to say, whether OFDI plays a promoting role in product innovation, patent innovation, and productivity improvement of firms. The OFDI activities and firms' innovation may have a two-way influence. In order to avoid endogeneity and sample selection bias, we adopted the PSM-DID method for empirical testing [53,54].

On the basis of propensity score matching, considering that OFDI occurs in multiple periods, the following double difference DID measurement regression was constructed for testing.

$$
\mathrm{INV}_{\mathrm{it}}=\beta_{0}+\beta_{1} \mathrm{OFDI}_{\mathrm{it}} \times \text { Year }_{i \mathrm{it}}+\beta_{3} \mathrm{M}_{\mathrm{it}}+\mu_{\mathrm{i}}+\tau_{\mathrm{t}}+\varepsilon_{\mathrm{it}}
$$

In Equation (9), firms' innovation (INV) is the dependent variable, which is represented by innovation quantity (LNIQ), innovation quality (LNIQ1), innovation efficiency (LNIE), and strategic innovation efficiency (LNSI). OFDI denotes whether a firm has made OFDI. If so, it is 1 , otherwise 0 . Year ${ }_{i t} 0$ represents before OFDI and 1 after OFDI. $M$ is the set of control variables related to the firms' characteristics. $\mu_{i}$ and $\tau_{t}$ represent fixed effects of industry and year, respectively, and $\varepsilon_{\text {it }}$ represents random disturbance item.

Based on Equation (9), this paper further investigates whether different entry modes of OFDI have different innovation effects. Model_1 represents the firms making greenfield 
investment, and Model_2 represents the firms making cross-border M\&A. The model is extended as follows:

$$
\mathrm{INV}_{\text {it }}=\beta_{0}+\sum_{\tau=1}^{2} \beta_{\tau} \mathrm{OFDI}_{\mathrm{it}} \times \text { Year }_{\mathrm{it}} \times \text { Model_} \_+\beta_{3} \mathrm{M}_{\mathrm{it}}+\mu_{\mathrm{i}}+\tau_{\mathrm{t}}+\varepsilon_{\mathrm{it}}
$$

We used $\beta_{\tau}(\tau=1,2)$ to compare the impact of different entry modes of OFDI on the level of firms' innovation, and other variables were the same as Formula (10).

\section{Empirical Analysis}

\subsection{Balance Test for Matching}

Firstly, we adopted propensity score matching year by year to construct counterfactual results and obtain the matching control group. As it was impossible to observe the situation that OFDI does not occur in the treatment group in reality, we matched the closest sample from the objects without OFDI as the control group. Then, the influence of OFDI on firms' innovation was obtained by using the control group as the reference. When the data were matched, we controlled the propensity scores of all samples in the same interval to meet the overlap hypothesis of samples. We tested the balance hypothesis of score matching in each year to prove the reliability of the matching results. Due to limited space, we only report the matching results of 2010 and 2011 in Table 2. The balance test results showed that the standard deviations of the matching variables were all controlled below $10 \%$ and the t-statistics after matching were not significant, which indicates that there is no significant systematic difference between the matching variables in the treatment group and the control group after matching. The overall matching effect was ideal.

Table 2. Matching balance test results.

\begin{tabular}{cccccc}
\hline \multirow{2}{*}{ Variable } & \multicolumn{2}{c}{ Mean } & \%Bias & t-Value & $p>|\mathbf{t}|$ \\
\cline { 2 - 3 } & Treated & Control & & & \\
\hline 2010 & & & & & \\
Lnw & 7.703 & 7.679 & 2 & 0.12 & 0.903 \\
Ownship & 0.365 & 0.383 & -3.8 & -0.23 & 0.822 \\
Rdrate & 3.259 & 3.356 & -3.2 & -0.20 & 0.844 \\
Years & 12.270 & 12.477 & -5.1 & -0.28 & 0.783 \\
Siz & 21.486 & 21.482 & 0.3 & 0.02 & 0.986 \\
\hline 2011 & & & & & \\
Lnw & 7.700 & 7.713 & -1.0 & -0.10 & 0.918 \\
Ownship & 0.314 & 0.312 & 0.4 & 0.04 & 0.969 \\
Rdrate & 3.652 & 3.514 & 4.4 & 0.41 & 0.683 \\
Years & 12.564 & 12.407 & 3.7 & 0.35 & 0.724 \\
Siz & 21.582 & 21.611 & -2.3 & -0.23 & 0.819 \\
\hline
\end{tabular}

\subsection{Different in Different Results and Analysis}

Using Chinese A-share listed firms from 2009 to 2019, this paper investigates the impact of OFDI on firms' innovation by using different in different method. The results are shown in Table 3. When the dependent variables were LnIQ, LnIQ1, and LnIE, the coefficient of the interaction term was significantly positive at the $1 \%$ level, indicating that the OFDI has a significant promotion effect of firms' innovation quantity, innovation quality, and innovation efficiency; Hypothesis 1 was confirmed. There is a certain gap between China and developed countries, because the original innovation ability of Chinese firms is still relatively weak. Therefore, a certain amount of innovation investment and time are required to digest and absorb new technological knowledge for firms. Concurrently, in the face of fierce competition from countries with higher levels of innovation, firms have to increase their independent innovation ability to achieve technological breakthroughs and upgrades. For the dependent variable LNSI, the coefficient of interaction term was not 
significant, indicating that OFDI does not promote the generation of strategic innovation behavior. A possible reason is that enterprises conduct OFDI to promote high quality innovation, and the opportunity cost of applying it to strategic innovation is very high.

Table 3. PSM-DID regression results.

\begin{tabular}{ccccc}
\hline & $\mathbf{( 1 )}$ & $\mathbf{( 2 )}$ & $\mathbf{( 3 )}$ & $\mathbf{( 4 )}$ \\
\hline Variable & LnIQ & LnIQ1 & LnIE & LnSI \\
\hline OFDI $_{\text {it }} \times$ Year $_{\text {it }}$ & $0.155^{* * *}$ & $0.136^{* * *}$ & $0.075^{* * *}$ & 0.004 \\
Rdrate & $(0.038)$ & $(0.038)$ & $(0.029)$ & $(0.011)$ \\
& $0.038^{* * *}$ & $0.056^{* * *}$ & $-0.016^{* * *}$ & $-0.011^{* * *}$ \\
Ownship & $(0.006)$ & $(0.009)$ & $(0.003)$ & $(0.002)$ \\
& $0.077^{*}$ & $0.166^{* * *}$ & $0.128^{* * *}$ & $-0.037^{* * *}$ \\
ROA & $(0.040)$ & $(0.041)$ & $(0.032)$ & $(0.011)$ \\
& $0.015^{* * *}$ & $0.015^{* * *}$ & -0.000 & $-0.003^{* * *}$ \\
Lnw & $(0.003)$ & $(0.003)$ & $(0.002)$ & $(0.001)$ \\
& $0.464^{* * *}$ & $0.354^{* * *}$ & $0.287^{* * *}$ & $0.047^{* * *}$ \\
Lntfp & $(0.026)$ & $(0.025)$ & $(0.023)$ & $(0.006)$ \\
& $0.064^{* *}$ & $0.170^{* * *}$ & $0.331^{* * *}$ & $-0.060^{* * *}$ \\
Constant & $(0.032)$ & $(0.034)$ & $(0.027)$ & $(0.009)$ \\
R-squared & $-2.083^{* * *}$ & $-2.841^{* * *}$ & $-4.027^{* * *}$ & $0.662^{* * *}$ \\
Company FE & $(0.228)$ & $(0.257)$ & $(0.176)$ & $(0.063)$ \\
Year FE & 0.189 & 0.202 & 0.372 & 0.045 \\
YES & YES & YES & YES & YES \\
\end{tabular}

Notes: The t-statistics in parentheses are based on robust standard errors clustered at the firm level. ${ }^{*}, * *$ and *** indicate statistical significance at the $10 \%, 5 \%$, and $1 \%$ levels, respectively.

\subsection{Comparison of Innovation Effects of Different Entry Modes of OFDI}

We estimated Model (10), where innovation quality, innovation quantity, innovation efficiency, and strategic innovation indexes were selected as dependent variables. We focused on the impact of different OFDI entry modes on innovation quality, and further selected the indicators of innovation quantity, innovation efficiency and strategic innovation for comparative analysis. The heterogeneity of greenfield investment and cross-border M\&A on firms' innovation levels was judged by comparing the coefficients of interaction terms OFDI $_{i t} \times$ Year $_{\text {it }} \times$ Model_1 and OFDI it $\times$ Year $_{\text {it }} \times$ Model_2. The estimated results are shown in Table 4. According to Column (1), the coefficients of interaction terms

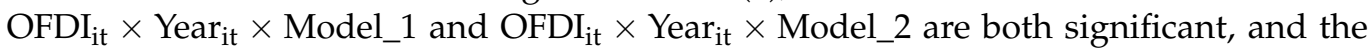
latter is slightly greater than the former. The results show that both greenfield investment and cross-border M\&A contribute to the increase of innovation quality, while cross-border M\&A has more advantages in promoting innovation quality. Hypothesis 2 was confirmed. According to Column (2), both contribute to the improvement of innovation quantity, but greenfield investment has a slight advantage in promoting the number of innovations. It can be concluded from (3) and (4) that the two open modes have a positive effect on innovation efficiency, and neither produces strategic innovation behavior.

The above verifies the impact of different OFDI modes on the level of firms' innovation, but is this impact sustainable? Next, we studied the impact of different OFDI entry modes on firms' innovation when the time changes. We chose two commonly used proxy indicators of corporate innovation level as the dependent variables (number of innovations and quality of innovation). The results are shown in Table 5. The coefficient of interaction

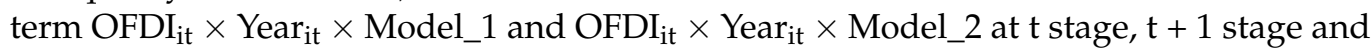
$t+2$ stage are all significant at $1 \%$ level. It showed that the impact of greenfield investment and cross-border M\&A on firms' innovation is sustainable. Meanwhile, from the coefficients of the two interaction terms in columns (1)-(3), it shows that greenfield investment plays a better role in promoting the number of innovations than cross-border M\&A. According to columns (4)-(6), we can conclude that in period $t$, the impact of cross-border M\&A on 
innovation quality is better than greenfield investment; in period $t+1$, the innovation effect of greenfield investment is slightly higher than cross-border M\&A; and in period $t+2$, the impact of cross-border M\&A is stronger than that of greenfield investment. In addition, from the change trend of the coefficient of the two interaction terms, we can draw the conclusion that the difference of the impact of the two on the innovation quality is gradually narrowing. Hypothesis 3 was confirmed.

Table 4. Impact of OFDI's different entry modes on innovation.

\begin{tabular}{ccccc}
\hline & $\mathbf{( 1 )}$ & $\mathbf{( 2 )}$ & $\mathbf{( 3 )}$ & $\mathbf{( 4 )}$ \\
\hline Variable & LnIQ1 & LnIQ & LnIE & LnSI \\
\hline OFDI $_{\text {it }} \times$ Year $_{\text {it }} \times$ Model_1 & $0.113^{* * *}$ & $0.138^{* * *}$ & $0.068^{* *}$ & 0.012 \\
OFDI $_{\text {it }} \times$ Year $_{\text {it }} \times$ Model_2 & $(0.037)$ & $(0.038)$ & $(0.029)$ & $(0.010)$ \\
& $0.149^{* * *}$ & $0.129^{* * *}$ & $0.071^{*}$ & -0.020 \\
Constant & $(0.047)$ & $(0.049)$ & $(0.036)$ & $(0.013)$ \\
& $-2.834^{* * *}$ & $-2.105^{* * *}$ & $-4.032^{* * *}$ & $0.644^{* * *}$ \\
R-squared & $(0.254)$ & $(0.226)$ & $(0.173)$ & $(0.063)$ \\
Control variable & 0.202 & 0.189 & 0.373 & 0.046 \\
Company FE & YES & YES & YES & YES \\
Year FE & YES & YES & YES & YES \\
& YES & YES & YES & YES \\
\hline
\end{tabular}

Notes: The t-statistics in parentheses are based on robust standard errors clustered at the firm level. * ${ }^{* *}$, and *** indicate statistical significance at the $10 \%, 5 \%$, and $1 \%$ levels, respectively.

Table 5. Sustainable innovation effects of OFDI's different entry modes.

\begin{tabular}{|c|c|c|c|c|c|c|}
\hline & (1) & (2) & (3) & (4) & (5) & (6) \\
\hline & t Stage & $t+1$ Stage & $t+2$ Stage & t Stage & $t+1$ Stage & $t+2$ Stage \\
\hline Variable & LnIQ & LnIQ & LnIQ & LnIQ1 & LnIQ1 & LnIQ1 \\
\hline OFDI $_{i t} \times$ Year $_{i t} \times$ Model_1 & $\begin{array}{c}0.138^{* * *} \\
(0.038)\end{array}$ & $\begin{array}{c}0.158^{* * *} \\
(0.037)\end{array}$ & $\begin{array}{c}0.152^{* * *} \\
(0.041)\end{array}$ & $\begin{array}{c}0.113^{* * * *} \\
(0.037)\end{array}$ & $\begin{array}{c}0.124^{* * *} \\
(0.037)\end{array}$ & $\begin{array}{c}0.109 * * * \\
(0.040)\end{array}$ \\
\hline OFDI $_{\text {it }} \times$ Year $_{i t} \times$ Model_2 & $\begin{array}{c}0.129 * * * \\
(0.049)\end{array}$ & $\begin{array}{l}0.093 \text { * } \\
(0.050)\end{array}$ & $\begin{array}{l}0.099 \text { * } \\
(0.056)\end{array}$ & $\begin{array}{c}0.149^{* * *} \\
(0.047)\end{array}$ & $\begin{array}{l}0.108 * * \\
(0.046)\end{array}$ & $\begin{array}{l}0.128^{* *} \\
(0.054)\end{array}$ \\
\hline Constant & $\begin{array}{c}-2.105^{* * *} \\
(0.226)\end{array}$ & $\begin{array}{c}-2.095^{* * *} \\
(0.227)\end{array}$ & $\begin{array}{c}-2.441^{* * *} \\
(0.222)\end{array}$ & $\begin{array}{c}-2.834^{* * * *} \\
(0.254)\end{array}$ & $\begin{array}{c}-2.520 * * * \\
(0.244)\end{array}$ & $\begin{array}{c}-2.751^{* * *} \\
(0.247)\end{array}$ \\
\hline R-squared & 0.189 & 0.172 & 0.188 & 0.202 & 0.168 & 0.180 \\
\hline Control variable & YES & YES & YES & YES & YES & YES \\
\hline Company FE & YES & YES & YES & YES & YES & YES \\
\hline Year FE & YES & YES & YES & YES & YES & YES \\
\hline
\end{tabular}

Notes: The t-statistics in parentheses are based on robust standard errors clustered at the firm level. ${ }^{*}, * *$ and ${ }^{* * *}$ indicate statistical significance at the $10 \%, 5 \%$, and $1 \%$ levels, respectively.

In conclusion, both cross-border M\&A and greenfield investment have a positive impact on innovation. However, the resource conversion ability of enterprises leads to different innovation effects due to the different external cost and internal resource integration cost. Compared with cross-border M\&A, greenfield investment needs to adapt to the external environment and be familiar with local laws, regulations, and policies in order to obtain local resources in the host country, resulting in a series of external costs. At the same time, greenfield investment keeps close contact with domestic enterprises at the beginning of its establishment and internal costs always exist. The internal and external costs of greenfield investment are greater than that of cross-border M\&A. As time goes by, greenfield investment enterprises gradually overcome the disadvantage of outsiders through experience accumulation. Therefore, it can be concluded that at the beginning of OFDI, cross-border M\&A plays a stronger role in promoting innovation quality, and as time goes by, the difference between cross-border M\&A and greenfield investment on innovation quality decreases gradually. 


\subsection{The Mediating Role of Government Resources}

In this section, we used a gradual regression method to examine whether different OFDI modes improved the firms' innovation levels through government innovation subsidies. The quality of innovation was selected as the dependent variables. The innovation subsidy was measured by GovRD, which refers to the proportion of the government's innovation subsidy to the company in the total assets. Column (1)-(3) and (4)-(6) of Table 6 test whether government subsidies are an effective channel to promote greenfield investment and M\&A. As can be seen in Table 6, the coefficient of independent variable in column (1) is positive, indicating that government subsidies have been significantly improved after the occurrence of greenfield investment. Column (2) indicates that greenfield investment has significantly promoted the improvement of firms' innovation quality. After government subsidies were added to the regression model in Column (3), the explanatory coefficient decreases, indicating that greenfield investment will promote firms and improve firms innovation quality through increasing government subsidies. Column (4)-(6) are the results of the mediating effect of cross-border M\&A on firms' innovation, indicating that the increase of government subsidies has a positive effect on promoting firms' innovation quality after cross-border M\&A. It shows that when a firm conducts M\&A or greenfield investment, it reflects the good relationship between the firm and the government. Meanwhile, the signal that the enterprise is capable and trustworthy is transmitted to the government, making it easier for the enterprise to obtain government resources. The government helps enterprises overcome the problem of insufficient investment in research and development through financial means, such as subsidies. After enterprises obtain government resources, they will send positive signals to the outside so as to obtain more support from venture capital and more attention, which promotes the improvement of enterprise innovation quality. Further, we compared the mediating effect ratio of government subsidies between greenfield investment (0.169) and cross-border M\&A (0.462), and found that the mediating effect of government subsidies on cross-border M\&A firms is stronger, and the channel of effect is more obvious. This shows that the grafting of government resources is more important for the innovation and development of cross-border M\&A enterprises. Hypothesis 4 was verified.

Table 6. The mediating effect test of government resources.

\begin{tabular}{|c|c|c|c|c|c|c|}
\hline & \multicolumn{3}{|c|}{ Greenfield } & \multicolumn{3}{|c|}{ M\&A } \\
\hline & (1) & (2) & (3) & (4) & (5) & (6) \\
\hline Variable & GovRD & LnIQ1 & LnIQ1 & GovRD & LnIQ1 & LnIQ1 \\
\hline OFDI $_{\text {it }} \times$ Year $_{\text {it }} \times$ Model_1 & $\begin{array}{l}0.623^{* * *} \\
(0.054)\end{array}$ & $\begin{array}{l}0.442^{* * *} \\
(0.037)\end{array}$ & $\begin{array}{l}0.379 * * * \\
(0.040)\end{array}$ & & & \\
\hline OFDI $_{i t} \times$ Year $_{i t} \times$ Model_2 & & & & $\begin{array}{l}0.392 * * * \\
(0.085)\end{array}$ & $\begin{array}{c}0.304^{* * *} \\
(0.078)\end{array}$ & $\begin{array}{c}0.148^{* *} \\
(0.074)\end{array}$ \\
\hline GovRD & & & $\begin{array}{l}0.120^{* * *} \\
(0.012)\end{array}$ & & & $\begin{array}{c}0.358^{* * *} \\
(0.022)\end{array}$ \\
\hline Constant & $\begin{array}{c}13.027^{* * *} \\
(0.189)\end{array}$ & $\begin{array}{l}1.406^{* * *} \\
(0.105)\end{array}$ & $\begin{array}{l}-0.178 \\
(0.207)\end{array}$ & $\begin{array}{l}4.014^{* * *} \\
(0.249)\end{array}$ & $\begin{array}{l}0.988^{* * *} \\
(0.172)\end{array}$ & $\begin{array}{l}-0.484^{* *} \\
(0.220)\end{array}$ \\
\hline R-squared & 0.254 & 0.091 & 0.119 & 0.251 & 0.088 & 0.247 \\
\hline Control variable & YES & YES & YES & YES & YES & YES \\
\hline Company FE & YES & YES & YES & YES & YES & YES \\
\hline Year FE & YES & YES & YES & YES & YES & YES \\
\hline
\end{tabular}

Notes: The t-statistics in parentheses are based on robust standard errors clustered at the firm level. ${ }^{* *}$, and ${ }^{* * *}$ indicate statistical significance at the $5 \%$, and $1 \%$ levels, respectively.

\subsection{Robustness Checks}

One of our concerns with differential differences is that some unobservable characteristic variables that change over time can affect the results. We cannot add all control variables that may affect the results, but an indirect placebo test can alleviate this concern. 
Based on the treatment methods of Li et al. (2016) and Cantoni et al. (2017) $[55,56]$, this paper constructed a placebo test to determine whether the promotion effect of greenfield and cross-border M\&A on innovation is caused by other random factors. We randomly generated the treatment group and repeated the regression 1000 times, producing $1000 \hat{\beta}^{\text {random }}$. As shown in Figure 1, it was found that $\hat{\beta}^{\text {random }}$ of greenfield investment and cross-border $M \& A$ is distributed around 0 and obeys the normal distribution, indicating that the placebo test passed.

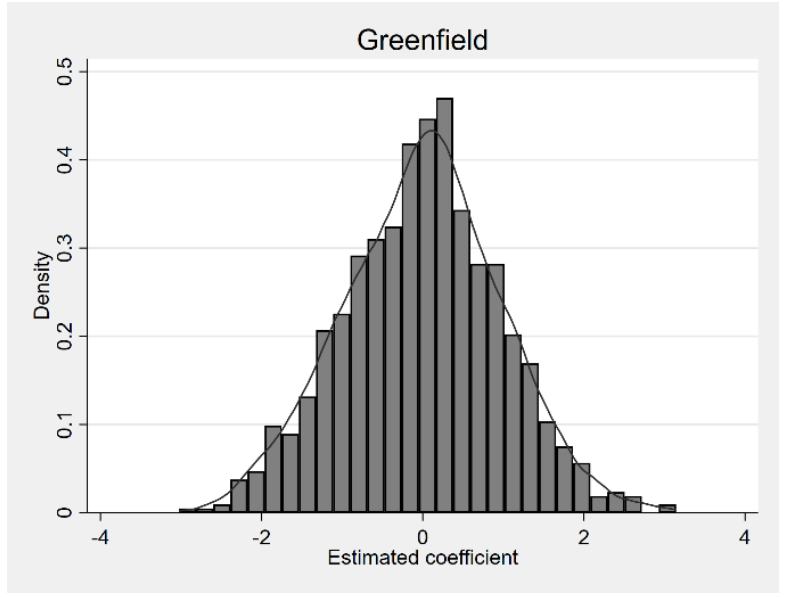

(a)

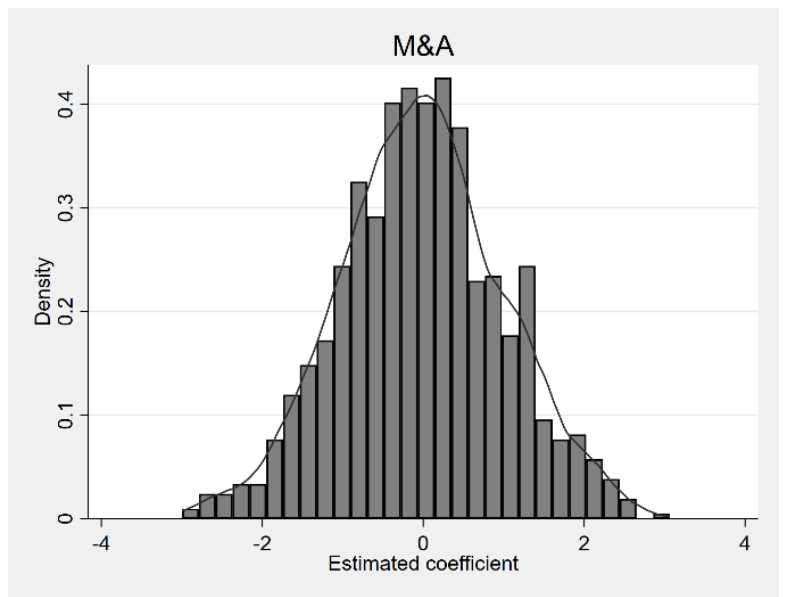

(b)

Figure 1. (a) Represents the distribution of $\hat{\beta}^{\text {random }}$ after random treatment of greenfield investment; and (b) represents the distribution of $\hat{\beta}^{\text {random }}$ after random treatment of cross-border M\&A.

\section{Conclusions}

We built a model and used the data of Chinese A-share listed firms as a sample to study whether OFDI and different OFDI entry modes can promote the innovation of Chinese firms, in which we selected the innovation quantity, innovation quality, and innovation efficiency indicators to measure the level of innovation. The results show that OFDI has a significant promoting effect on the level of innovation. Further analysis shows that greenfield investment promotes the innovation quantity better than cross-border M\&A, while cross-border M\&A plays a stronger role in promoting the innovation quality. Both of the two open modes have a positive effect on the innovation efficiency, and neither of them produces strategic innovation behaviors. As time goes by, the gap between the two impacts on innovation quality is gradually narrowing, and both have sustainable innovation behaviors. From the perspective of mechanism, the signaling effect of the firms' greenfield and cross-border M\&A is conducive to their involvement in government resources, but by contrast, government subsidies have a stronger intermediary effect on cross-border M\&A and the channel of effect is more obvious.

Influenced by the COVID-19 pandemic, the sharp global economic recession, and the intensifying geopolitical competition among major countries, the rational evaluation of greenfield investment and cross-border M\&A of enterprises can provide reference for China and other emerging countries to implement OFDI. Therefore, this study has profound practical significance for government decision making and firms' managers. From the perspective of the government, it is still a major participant in economic activities, whose role cannot be ignored in the ecosystem composed of open innovation. The government should unswervingly expand the opening up to the outside world and send a stronger signal of government support to the market, so as to promote firms to obtain resources and promote innovation to a greater extent. However, we cannot blindly encourage all firms to go out, but rather to cultivate and foster a number of high-quality firms with international competitive advantages which can choose the appropriate way to go 
out. The government should overcome the fetters of an unfavorable environment and create a fair competition environment for firms. Specifically, the government should do a good job in investment service and promotion, and strengthen policy communication and coordination with the host government, and at the same time, with relatively abundant capital, allocate and utilize global human and scientific and technological resources to promote the development of firms' innovation levels. From the perspective of enterprise managers, firms should have an international vision and actively go out to integrate into the global innovation network. Before "go out", firms should combine their own scale, performance, experience, and other resource advantages. In addition, they should fully study the market environment of the host country and choose the optimal entry mode, which directly affects internal and external resource commitments, costs, risk level, and the company's ultimate level of innovation. After "go out", firms should make full use of the perfect innovation infrastructure, innovation transformation platform, and the accumulation of innovation elements in the region to improve their independent $R \& D$ and innovation capabilities.

This study is not without limitations and future work may explore the following issues. Firstly, patent as an agency indicator of innovation. Enterprises may have different patent application preferences due to different technology protection strategies, and some enterprises improve the level of innovation by acquiring intangible proprietary technology, so patents could not fully represent enterprise innovation. Future research could build a more perfect enterprise innovation index measurement system. Secondly, in the selection of samples, non-listed companies were excluded due to the unavailability of key information. If a sample of non-listed companies is added for comparative analysis, the research results may be more convincing. Future research can overcome this deficiency based on multiple case studies. Finally, this paper is an exploratory attempt to study the impact of China's listed companies' OFDI entry modes on enterprise innovation. In the future, we may study the impact of formal institutional distance and informal institutional distance and the embeddedness of innovation networks on the innovation of enterprises in their home countries under different OFDI modes.

Author Contributions: The authors worked together for this research. Conceptualization, Z.Z. and C.X.; methodology, software validation, and resources, Z.Z., C.X., and A.F.; data analysis, C.X.; writing-original draft preparation, Z.Z. and C.X.; writing-review and editing, Z.Z., C.X. and A.F. All authors have read and agreed to the published version of the manuscript.

Funding: This research received no external funding.

Institutional Review Board Statement: Not applicable.

Informed Consent Statement: Not applicable.

Data Availability Statement: Please contact corresponding author.

Acknowledgments: The authors thank the editor and anonymous reviewers for their useful comments and suggestions.

Conflicts of Interest: The authors declare no conflict of interest.

\section{References}

1. Zhuang, Z.; Jia, H.; Xiao, C. Research Progress on Breakthrough Innovations. Econ. Perspect. 2020, 9, 145-160.

2. Chen, J. Newly National Innovation System for S\&T Powerhouse. Bull. Chin. Acad. Sci. 2018, 33, 479-483.

3. Zhu, Z.; Huang, X.; Wang, Y. FDI Entry and the Solution to the Double Low Dilemma of Chinese Innovation. Econ. Res. J. 2020, $55,99-115$.

4. Fu, X.; Hou, J.; Liu, X. Unpacking the Relationship between Outward Direct Investment and Innovation Performance: Evidence from Chinese firms. World Dev. 2018, 102, 111-123. [CrossRef]

5. Wu, J.; Wang, C.Q.; Hong, J.J.; Piperopoulos, P.; Zhuo, S.H. Internationalization and innovation performance of emerging market enterprises: The role of host-country institutional development. J. World Bus. 2016, 51, 251-263. [CrossRef]

6. Ai, Q.; Tan, H. Acquirers' prior related knowledge and post-acquisition integration Evidences from four Chinese firms. J. Organ. Chang. Manag. 2017, 30, 647-662. [CrossRef] 
7. Luo, Y.D.; Tung, R.L. International expansion of emerging market enterprises: A springboard perspective. J. Int. Bus. Stud. 2007, 38, 481-498. [CrossRef]

8. Mathews, J.A. Dragon multinationals: New players in 21 st century globalization. Asia Pac. J. Manag. 2006, 23, 5-27. [CrossRef]

9. Zheng, N.; Wei, Y.; Zhang, Y.; Yang, J. In search of strategic assets through cross-border merger and acquisitions: Evidence from Chinese multinational enterprises in developed economies. Int. Bus. Rev. 2015, 25, 177-186, S0969593114001887. [CrossRef]

10. Stiebale, J. The impact of cross-border mergers and acquisitions on the acquirers' R\&D—Firm-level evidence. Int. J. Ind. Organ. 2013, 31, 307-321.

11. Li, Y.; He, C.; Liu, Y.; Kong, L. Can direct investment in the Belt and Road countries promote innovation of Chinese listed companies? Stud. Sci. Sci. 2020, 38, 1509-1525.

12. Jia, N.; Han, Y.; Lei, H. A research on the innovation effect of China's outward foreign direct investment. Sci. Res. Manag. 2020, $41,122-130$.

13. Bitzer, J.; Kerekes, M. Does foreign direct investment transfer technology across borders? New evidence. Econ. Lett. 2008, 99, 355-358. [CrossRef]

14. Edamura, K.; Haneda, S.; Inui, T.; Tan, X.; Todo, Y. Impact of Chinese cross-border outbound M\&As on firm performance: Econometric analysis using firm-level data. China Econ. Rev. 2014, 30, 169-179.

15. Pradhan, J.P.; Singh, N. Outward FDI and Knowledge Flows: A Study of the Indian Automotive Sector. Int. J. Inst. Econ. 2008, $1,155-186$.

16. Cowling, K.; Tomlinson, P.R. The Problem of Regional 'hollowing Out' in Japan: Lessons for Regional Industrial Policy; Edward Elgar Publishing Ltd.: Cheltenham, UK, 2003; pp. 33-58.

17. Ma, C.L.; Liu, Z.Y. Effects of M\&As on innovation performance: Empirical evidence from Chinese listed manufacturing enterprises. Technol. Anal. Strateg. Manag. 2017, 29, 960-972.

18. Zhou, C.Y.; Hong, J.; Wu, Y.R.; Marinova, D. Outward foreign direct investment and domestic innovation performance: Evidence from China. Technol. Anal. Strateg. Manag. 2019, 31, 81-95. [CrossRef]

19. Kolstad, I.; Wiig, A. What determines Chinese outward FDI? J. World Bus. 2012, 47, 26-34. [CrossRef]

20. Ping, D. Why do Chinese firms tend to acquire strategic assets in international expansion? J. World Bus. 2009, $44,74-84$.

21. Rossi, M.; Yedidia Tarba, S.; Raviv, A. Mergers and acquisitions in the hightech industry: A literature review. Int. J. Organ. Anal. 2013, 21, 66-82. [CrossRef]

22. Barney, J. Firms resources and sustained competitive advantages. J. Manag. 1991, 17, 99-120. [CrossRef]

23. Rossi, M.; Demetris Vrontis, D.M.C.P.; Thrassou, A.; Vrontis, D. Biotechnological mergers and acquisitions: Features, trends and new dynamics. J. Res. Mark. Entrep. 2015, 17, 91-109. [CrossRef]

24. Ossorio, M. Does R\&D investment affect export intensity? The moderating effect of ownership. Int. J. Manag. Financ. Account. 2018, 10, 65-83.

25. Anand, J.; Delios, A. Absolute and relative resources as determinants of international acquisitions. Strateg. Manag. J. 2002, 23, 119-134. [CrossRef]

26. Becker, J.; Fuest, C. Tax Competition-Greenfield Investment versus Mergers and Acquisitions. CESifo Work. Pap. Ser. 2008, 41, 476-486. [CrossRef]

27. Brouthers, K.D. Institutional, Cultural and Transaction Cost Influences on Entry Mode Choice and Performance. J. Int. Bus. Stud. 2013, 44, 14-22. [CrossRef]

28. Brouthers, K.D.; Brouthers, L.E. Acquisition or greenfield start-up? Institutional, cultural and transaction cost influences. Strateg. Manag. J. 2000, 21, 89-97. [CrossRef]

29. Buch, C.M.; Kesternich, I.; Lipponer, A.; Schnitzer, M. Financial constraints and foreign direct investment: Firm-level evidence. Rev. World Econ. 2014, 150, 393-420. [CrossRef]

30. Jiang, G.; Jiang, D. Greenfield Investment or Cross border Mergers and Acquisitions: A Research on Chinese Companies outward Investments. J. World Econ. 2017, 40, 126-146.

31. Nocke, V.; Yeaple, S. Cross-border mergers and acquisitions vs. greenfield foreign direct investment: The role of firm heterogeneity-ScienceDirect. J. Int. Econ. 2007, 72, 336-365. [CrossRef]

32. Yan, Z.J.; Zhu, J.C.; Fan, D.; Kalfadellis, P. An institutional work view toward the internationalization of emerging market firms. J. World Bus. 2018, 53, 682-694. [CrossRef]

33. Wang, J.; Huang, L.Y. Effect of Policy Subsidy on OFDI Firms' Product Innovation. R. D. Manag. 2017, 29, 87-97.

34. Buitrago, R.R.E.; Barbosa Camargo, M.I. Home Country Institutions and Outward FDI: An Exploratory Analysis in Emerging Economies. Sustainability 2020, 12, 10010. [CrossRef]

35. Chen, A.-Z.; Zhang, P.-F. M\&A Mode and Enterprise's Innovation. China Ind. Econ. 2019, 12, 115-133.

36. D'Aspremont, C.; Jacquemin, A. Cooperative and noncooperative R\&D in duopoly with spillovers: Erratum. Am. Econ. Rev. 1990, $80,641-642$.

37. Hennart, J.-F.; Park, Y.-R. Greenfield vs. acquisition: The strategy of Japanese investors in the United States. Manag. Sci. 1993, 39, 1054-1070. [CrossRef]

38. Drogendijk, R.; Andersson, U. Relationship development in Greenfield expansions. Int. Bus. Rev. 2013, 22, 381-391. [CrossRef]

39. Yi, R.; Ping, L. Dynamic Performance Comparison of Greenfield and Cross-border Acquisition. Bus. Manag. J. 2014, 36, 146-156.

40. Liu, C.; Tian, L. Can Talent Policy Endorsement Promote Firm Innovation. China Ind. Econ. 2021, 3, 156-173. 
41. Zhou, J.; Li, J.; Li, B.; Liu, Z. Cooperation and firm international innovation: The moderating role of government involvement. Sci. Res. Manag. 2018, 39, 46-55.

42. Zhang, Y.; Cheng, Y.; She, G. Can Government Subsidy Improve High-tech Firms' Independent Innovation? Evidence from Zhongguancun Firm Panel Data. J. Financ. Res. 2018, 10, 123-140.

43. Bhattacharya, U.; Hsu, P.H.; Tian, X.; Xu, Y. What Affects Innovation More: Policy or Policy Uncertainty? J. Financ. Quant. Anal. 2017, 52, 1869-1901. [CrossRef]

44. Kogan, L.; Papanikolaou, D.; Seru, A.; Stoffman, N. Technological innovation, resource allocation, and growth. Q. J. Econ. 2017, 132, 665-712. [CrossRef]

45. Li, J.; Xia, J.; Zajac, E.J. On the duality of political and economic stakeholder influence on firm innovation performance: Theory and evidence from Chinese firms. Strateg. Manag. J. 2017, 39, 193-216. [CrossRef]

46. Jiang, G.; Zeng, J. Financial Constraint and the Mode of Outward Foreign Direct Investment: Cross-border Merge or Green Field Investment. Financ. Trade Econ. 2020, 41, 134-147.

47. Fagerberg, J.; Mowery, D.C.; Nelson, R.R. The Oxford Handbook of Innovation; Oxford University Press: Oxford, UK, 2005; pp. 148-168.

48. Denicolò, V.; Polo, M. Duplicative research, mergers and innovation. Econ. Lett. 2018, 166, 56-59. [CrossRef]

49. Shi, J.; Li, X. Government Subsidies and Corporate Innovation Capability: A New Empirical Finding. Bus. Manag. J. 2021, 43, 113-128.

50. Liu, S.; Lin, Z.; Leng, Z. Whether Tax Incentives Stimulate Corporate Innovation: Empirical Evidence Based on Corporate Life Cycle Theory. Econ. Res. J. 2020, 55, 105-121.

51. Yao, L.; Zhou, Y. Managerial Ability, Innovation Ability and Innovation Efficiency. Account. Res. 2018, 6, 70-77.

52. Li, W.; Zheng, M. Is it Substantive Innovation or Strategic Innovation?-Impact of Macroeconomic Policies on Micro-enterprises' Innovation. Econ. Res. J. 2016, 51, 60-73.

53. Heyman, F.; Sjholm, F.; Tingvall, P.G. Is there really a foreign ownership wage premium? Evidence from matched employeremployee data. J. Int. Econ. 2007, 73, 355-376. [CrossRef]

54. Stiebale, J.; Vencappa, D. Acquisitions, markups, efficiency, and product quality: Evidence from India. Dice Discuss. Pap. 2016, 112, 70-87. [CrossRef]

55. Cantoni, D.; Chen, Y.; Yang, D.; Yuchtman, N.; Zhang, Y.J. Curriculum and Ideology. J. Political Econ. 2017, 125, 338-392. [CrossRef]

56. Li, P.; Lu, Y.; Wang, J. Does flattening government improve economic performance? Evidence from China. J. Dev. Econ. 2016, 123, 18-37. [CrossRef] 